\title{
KERAGAMAN GENETIK DAN MORFOMETRIK PADA IKAN BAUNG, Mystus nemurus DARI JAMBI, WONOGIRI, DAN JATILUHUR
}

\author{
Estu Nugroho"), Wartono Hadie"), Jojo Subagja"), dan Titin Kurniasih")
}

\begin{abstract}
ABSTRAK
Variasi genetik dan morfometrik beberapa ras ikan baung yang dikoleksi dari Jambi, Wonogiri, dan Jatiluhur telah diteliti dengan menggunakan polimorfisme mitokondria DNA D-10op dan metode truss morphometric. Berdasarkan kedua metode tersebut terdapat perbedaan yang nyata antara ras ikan baung dari Jambi dengan Wonogiri dan Jatiluhur, dan tidak berbeda nyata antara ras Jatiluhur dengan Wonogiri. Enam komposit haplotipe terdeteksi dengan menggunakan 4 enzim restriksi yaitu Msp I, Hae III, Hinc I, dan Mbo I pada sekuens D-loop, dengan diversitas haplotype rata-rata adalah 0,264 . Sekitar $35 \%$ ras ikan baung dari Jatiluhur mempunyai bentuk yang serupa dengan ikan baung dari Wonogiri.
\end{abstract}

ABSTRACT: Genetic divergence and morphometric variation of catfish, Mystus nemurus, collected from Jambi, Wonogiri, and Jatiluhur, by: Estu Nugroho, Wartono Hadie, Jojo Subagja, and Titin Kurniasih

The aim of this research is to evaluate genetic variability and identification of Mystus nemurus. The genetic variability of catfish collected from Jambi, Wonogiri, and Jatiluhur were examined using polymorphism of the mitochondria DNA (MtDNA) D-loop markers and truss morphometric. Based on the both analysis, there is significant difference between Jambi and Wonogiri, Jambi and Jatiluhur collections. Comparison between Jatiluhur and Wonogiri collection is not significantly different. Six composite haplotypes were detected following digestion of D-loop sequences with four endonucleases: Msp I, Hae III, Hins I, and Mbo I. The average Haplotype diversity was 0.264. About $35 \%$ individual of Jatiluhur has similar with those of Wonogiri collections.

KEYWORDS: genetic divergence, Mystus nemurus, Mt DNA d-loop, truss morphometric

\section{PENDAHULUAN}

Ikan baung (Mystus nemurus) merupakan salah satu jenis plasma nutfah air tawar yang didomestikasikan dari perairan umum. Keberhasilan upaya domestikasi ikan baung ini harus ditunjang teknologi dengan penerapan berbagai disiplin ilmu, sehingga untuk pengembangan selanjutnya dapat pula menjaga kelestarian sumber daya genetik di lingkungan alaminya. Salah satu aspek yang mempunyai peranan penting dalam pengembangan domestikasi adalah penyediaan benih maupun persiapan induk yang berkualitas baik untuk budi daya (Royce, 1984). Langkah awal yang perlu dilakukan adalah mengkarakterisasi secara genetis stok ikan baung. Pengumpulan informasi mengenai data dasar genetik dari suatu spesies merupakan syarat awal yang diperlukan untuk menentukan variasi genetik atau kekerabatan yang dimiliki.

Variasi genetik merupakan suatu informasi penting untuk evaluasi, baik dalam jangka pendek, mengenai fitness individu, maupun untuk jangka panjang yaitu sintasan dari suatu populasi (Ferguson et al., 1995). Variasi genetik dapat dievaluasi dengan dua cara yaitu dengan diversitas alel dan heterozigositas. Beberapa metoda dapat digunakan untuk mengestimasi tingkat variasi genetik yaitu penggunaan penciri molekuler (Carvalho \& Pitcher, 1995), termasuk di antaranya adalah DNA mitokondria (Park \& Morgan, 1995; Martin et al., 1992). Pengumpulan secara langsung variasi DNA ditemukan bersama dengan isolasi tentang ensim restriksi. Penerapan langsung teknik.ini diawali dengan DNA mitokondria. Teknik ini dapat dilakukan dengan menggunakan sample dalam keadaan segar, beku, ataupun yang disimpan dalam alkohol (Nugroho et al., 1997; Ward \& Grewe, 1995)

Pengamatan variasi genetik juga dapat dilakukan melalui analisis keragaan secara morfologis atau fenotipe (Gardrier et al., 1991). Salah satu metode yang dapat digunahan dalam menggambarkan bentuk tubuh ikan adalah truss morphometric (Strauss \& Bookstein, 1982). Penggunaan metode ini telah berhasil cukup baik pada beberapa spesies, antara lain ikan gurami (Tayaman et al., 1991), dan ikan mas (Nugroho et al., 1991).

\footnotetext{
Peneliti pada Balai Riset Perikanan Budidaya Air Tawar, Bogor

-) Peneliti pada Pusat Riset Perikanan Budidaya, Jakarta
} 
Penelitian ini dilakukan untuk mengetahui keragaman genetik koleksi ikan baung yang dimiliki Balai Riset Perikanan Budidaya Air Tawar (BRPBAT) Bogor, baik secara morfologi maupun DNA. Dengan diketahuinya variasi genetik dari masing-masing ras akan sangat membantu untuk menentukan program pemuliaan yang tepat pada tahapan berikutnya.

\section{BAHAN DAN METODE}

\section{Ikan Uji}

Ikan uji yang digunakan dalam penelitian ini adalah ikan baung yang berasal dari Sungai Batanghari Jambi, Waduk Jatiluhur, dan Gajah Mungkur-Wonogiri. Jumlah sampel per populasi yang digunakan untuk pengamatan secara morfologis adalah 40 ekor, dengan ukuran panjang total ikan berkisar antara $15--25 \mathrm{~cm}$, dan 20 di antaranya diambil secara acak untuk analisis DNA.

\section{Truss Morphometric}

Ikan yang digunakan diambil secara acak dari setiap populasi dan dipilih berdasarkan kelengkapan bentuk dan anggota tubuhnya. Ikan dibius dengan cara direndam dalam air yang mengandung MS 222 dengan konsentrasi $2 \mathrm{mg} / \mathrm{L}$. Setelah terbius, ikan diletakkan di atas kertas folio yang berlapis dengan kertas karbon di bawahnya. Penentuan tiga belas titik truss dilakukan dengan menggunakan jarum pada daerahdaerah yang telah ditentukan

\section{Mitokondria DNA D-loop}

\section{Ekstraksi DNA}

DNA ikan diekstraksi dari potongan sirip dengan menggunakan alat Wizard Genome DNA Purification (Promega), sebagai berikut: 5--10 mg potongan sirip ikan dimasukkan ke dalam tabung $1,5 \mathrm{~mL}$ yang telah berisi $500 \mu \mathrm{L}$ larutan lisis DNA + 120 larutan 0,5M EDTA pH 8,0. Kemudian ditambahkan $10 \mu \mathrm{g} / \mathrm{mL}$ protein kinase dan diinkubasikan pada suhu $55^{\circ} \mathrm{C}$ selama $3 \mathrm{jam}$. Sebanyak $3 \mu \mathrm{L}$ larutan Rnase ditambahkan ke dalam campuran tersebut, kemudian diinkubasikan pada suhu $37^{\circ} \mathrm{C}$ selama 30 menit. Setelah didinginkan pada suhu kamar, ditambahkan kedalamnya larutan Protein precipitation sebanyak $200 \mu \mathrm{L}$ dan disimpan dalam es selama 5 menit Kemudian disentrifus pada kecepatan 10.000 rpm selama 10 menit. Lapisan supernatannya diambil dan dimasukkan ke dalam tabung baru, dan ditambahkan $600 \mu \mathrm{L}$ larutan propanol dan divortex sampai terlihat endapan putih. DNA diendapkan dengan cara mensentrifus campuran tersebut pada kecepatan
10.000 rpm selama 10 menit, kemudian larutan di atasnya dibuang dan DNA dikeringkan pada suhu ruangan. Kemudian dilarutkan kembali dalam 50--100 $\mu \mathrm{L}$ Tris-EDTA (TE) buffer dan disimpan pada suhu $4^{\circ} \mathrm{C}$ sebelum digunakan pada tahap selanjutnya

\section{Amplifikasi daerah D-loop}

Primer yang digunakan untuk mengamplifikasi sekuens mitokondria D-loop dan sebagian cytohrome B adalah primer V-glue (CAT ATT AAA CCC GAA TGA TAT TT) dan primer HN-20 (ATAATA GGG TAT CTA ATC CTA GTT T). Pengamplifikasian dilakukan menggunakan metode Polymerize Chain Reaction (PCR) dengan komposisi reaksi yang terdiri: $10 \mu \mathrm{g}$, 10 pmol setiap primer dan pure taq DNA (Promega) dengan total volume keseluruhannya $25 \mu \mathrm{L}$. Siklus PCR yang digunakan dalam amplifikasi adalah satu siklus denaturasi pada suhu $95^{\circ} \mathrm{C}$ selama 2 menit. 35 siklus penggandaan yang terdiri atas $95^{\circ} \mathrm{C}$ selama 1 menit, $45^{\circ} \mathrm{C}$ selama 1 menit, dan $72^{\circ} \mathrm{C}$ selama 2.5 menit. Selanjutnya satu siklus terakhir pada suhu $72^{\circ} \mathrm{C}$ selama 10 menit. Sekuens MtDNA yang didapat direstriksi dengan menggunakan endonuklease sesuai dengan prosedur standar perusahaan. Hasil restriksi kemudian dipisahkan secara elektroforesis dengan menggunakan gel agarose $2 \%--3 \%$ dalam Tris-BoricEDTA (TBE) buffer dan diamati dengan illuminator (UV) serta dicetak gambarnya dengan polaroid.

\section{Analisis Data}

Untuk mengevaluasi variasi morfologi atau bentuk tubuh ikan baung digunakan analisis pembeda (discriminant analysis) dan analisis komponen utama (principle component analysis) yang dihitung dengan menggunakan program SAS. Sedangkan variasi DNA antar populasi ikan baung, susunan haplotipe untuk masing-masing enzim restriksi dikumpulkan sebagai komposit haplotipe dan dianalisis dengan menggunakan analisis molekuler varians (AMOVA) dan Fst dalam program ARLEQUIN (Schneider et al. 1996). Diversitas haplotipe atau diversitas gene dihitung berdasarkan Nei \& Tajima (1981) untuk mengamati tingkat variasi genetik yang ada Kekerabatan antar populasi dianalisis dengan menggunakan jarak genetik, D, dari Takezaki \& $\mathrm{Ne}$ (1996).

\section{HASIL DAN BAHASAN}

\section{Morfometrik}

Secara umum terdapat perbedaan yang nyata secara morfologi antara koleksi-koleksi ikan baung yang digunakan dalam penelitian ini. Berdasarkan analisis komponen utama (dengan step wise) 
didapatkan bahwa perbandingan ikan baung ras Jambi dan Wonogiri mempunyai nilai $F$ yang terbesar yaitu $195,1(P<0,01)$ kemudian diikuti antara Jambi dan Jatiluhur ( $F=183,3, P<0,01)$, dan antara Jatiluhur dan Wonogiri $(F=0,268, P>0,05)$. Fenomena tidak adanya perbedaan antara dua ras baung dari Jawa ini disebabkan adanya kemungkinan hubungan antara ras Wonogiri dan Jatiluhur yaitu salah satunya melalui jalur transportasi. Hal serupa juga terjadi pada ikan nila dari Jatiluhur, Cirata, dan Sukabumi (Nugroho et al., 2001). Sedangkan perbedaan antara ras ikan baung dari Jambi dan dua ras dari Jawa dimungkinkan adanya halangan atau barrier secara geografis dan masih minimnya alur lalu lintas peredaran ikan baung dari Jawa ke Sumatera atau sebaliknya sebagai akibat budi daya ikan baung yang masih pada taraf awal perkembangan.

Lebih jauh, hasil analisis fungsi kanonikal-pembeda menunjukkan bahwa ras Jambi terletak terpisah dari dua ras baung dari Jawa. Ras baung dari Jambi mempunyai keragaman yang paling kecil, kemudian diikuti keragaman ras baung dari Wonogiri dan Jatiluhur (Gambar 1). Analisis ini juga menunjukkan bahwa metode truss morphometric yang digunakan di sini dapat mengidentifikasi dengan tepat ras Jatiluhur yang benar sebesar $61,5 \%$, ras Wonogiri $(68,4 \%)$, dan Jambi $(97,5 \%)$. Selanjutnya diketahui bahwa $38,5 \%$ ras Jatiluhur mempunyai bentuk yang dapat digolongkan sebagai ras Wonogiri, dan sebaliknya $31,6 \%$ ras Wonogiri dikategorikan sebagai ras Jatiluhur. Sedangkan pada ras Jambi hanya sekitar $2,5 \%$ yang dikategorikan sebagai ras lainnya (Tabel 1). Fenomena ini semakin memperkuat pendapat bahwa adanya indikasi bahwa ras baung yang berasal dari Jatiluhur mempunyai hubungan kekerabatan dengan ras baung dari Wonogiri, sedangkan ras Jambi merupakan suatu ras yang terpisah. Keberhasilan metode truss morphometric dalam membedakan bentuk tubuh ikan ini serupa dengan hasil yang didapatkan oleh Nugroho et al. (1991) pada ikan mas dari berbagai daerah di Indonesia.

\section{Mitokondria DNA D-loop}

Sekuens Mt DNA D-loop ikan baung hasil PCR mempunyai panjang sekitar 1.800--2.000 bp. Empat dari tujuh enzim restriksi yang digunakan untuk memotong sekuens tersebut (Msp I, Hae III, Hinc I, dan Mbo I), mempunyai situs pemotongan. Polimorfisme pola pemotongan didapatkan pada keempat enzim restriksi tersebut. Pemotongan sekuens MtDNA D-loop dengan menggunakan enzim Hae III dan Hinc I menghasilkan dua jenis pola, sedangkan enzim Msp I mempunyai 3 pola dan Mbo I mempunyai 4 pola restriksi. Salah satu contoh dari pola pemotongan oleh salah satu enzim tercantum pada Gamivar 2. Panjang sekuens MtDNA D-loop ini

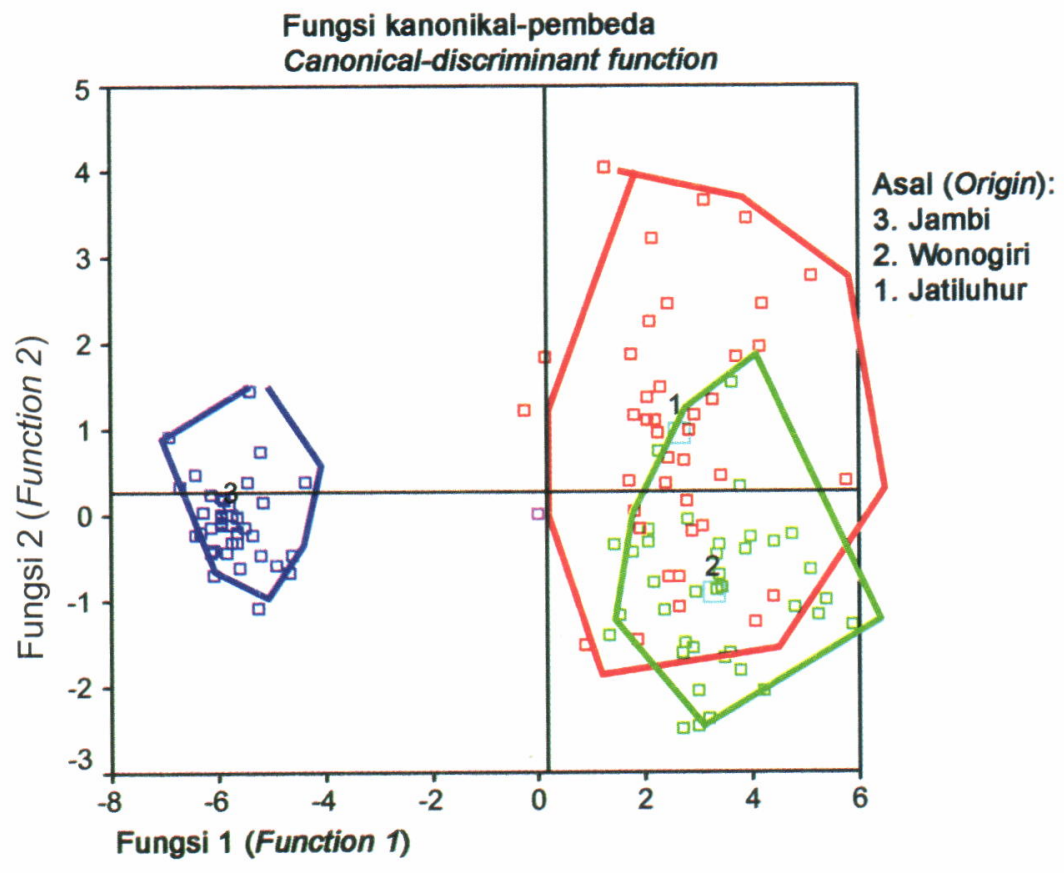

Gambar 1. Variasi dan pengelompokan sampel ikan baung berdasarkan analisis pembeda, Grup 1: Jatiluhur, 2: Wonogiri, 3: Jambi

Figure 1. Variation and classification of Mystus nemurus based on the discriminant analysis. Group 1: Jatiluhur, 2: Wonogiri, 3: Jambi 
Table 1. Identifikasi jenis ras ikan baung berdasarkan analisis kanonikal-pembeda. Nilai dalam kurung adalah persentase dari total setiap kelompok sampel yang dianalisis

Table 1. Identification of Mystus nemurus samples based on the canonical analysis. Values in the bracket are percent of the total number of sampel analyzed in each group

\begin{tabular}{lcccc}
\hline & Jambi & Wonogiri & Jatiluhur & Total \\
\hline Jambi & $39(97.5)$ & $1(2.5)$ & $0(0)$ & 40 \\
Wonogiri & $0(0)$ & $26(68.4)$ & $12(31.6)$ & 38 \\
Jatiluhur & $0(0)$ & $15(38.5)$ & $24(61.5)$ & 39 \\
\hline
\end{tabular}

setara dengan panjang sekuens daerah yang sama pada beberapa ikan lainnya seperti, nila, kingfish, yellow tail, dan red sea bream (Nugroho, 2001).

Secara umum ikan baung yang diteliti masih mempunyai tingkat keragaman yang cukup tinggi dengan nilai diversitas haplotype rata-rata adalah 0,264 (Tabel 2). Relatif tingginya variasi genetik pa da ikan baung ini dimungkinkan karena budi daya komoditas ini masih belum banyak dilakukan, sehingga keadaan populasi alam masih belum banyak terganggu. Selain itu, keadaan ini juga menunjukkan bahwa ikan baung mempunyai tingkat migrasi yang lebih tinggi dibandingkan ikan air tawar lainnya sehingga peluang untuk adanya persilangan dengan populasi (stok)

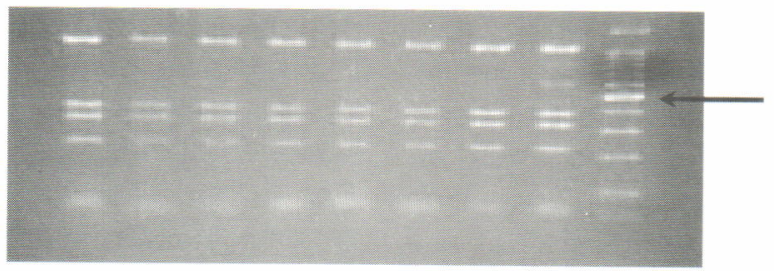

a) enzim Hae III

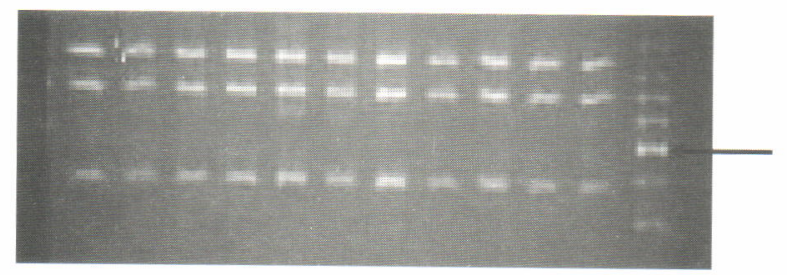

b) enzim Hinc II

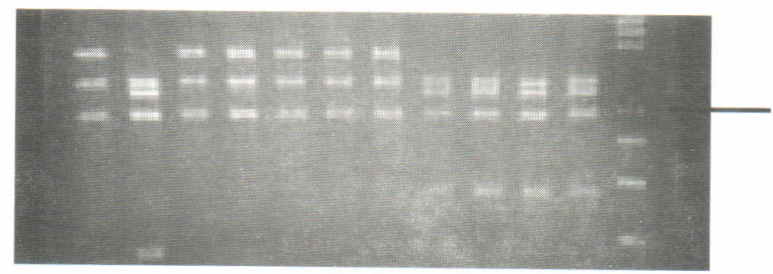

c) enzim Mbo I

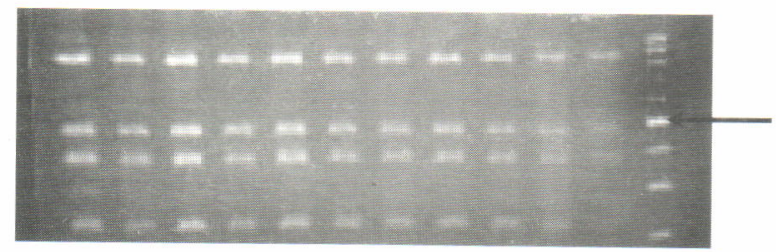

d) enzim Msp I

Gambar 2. Pola pemotongan daerah mtDNA D-loop ikan baung yang direstriksi dengan menggunakan 4 enzim endonuklease.(tanda panah menunjukkan panjang 500 bp)

Figure 2. Restriction site patterns of mtDNA D-loop freshwater catfish generated using 4 endonuclease (the arrow indicates $500 \mathrm{bp}$ of length) 
Tabel 2. Frekuensi haplotipe dari mt DNA D-loop ikan baung yang direstriksi dengan menggunakan 4 enzim, Msp I, Hae III, Hinc I, dan Mbo I

Table 2. Haplotype frequency of mt DNA D-loop region of Mystis nemurus generated by 4 endonucleases, Msp I, Hae III, Hinc I, and Mbo I

\begin{tabular}{lrcc}
\hline \multicolumn{1}{c}{ Haplotipe (Haplotype) } & Jambi & Wonogiri & Jatiluhur \\
\hline 1. AAAA & 0.944 & & - \\
2. AAAB & 0.006 & & - \\
3. AAAC & - & 0.571 & 0.904 \\
$\begin{array}{l}\text { 4. BBBD } \\
\text { 5. CBAC }\end{array}$ & - & 0.429 & - \\
\hline Jumlah sampel & 18 & 14 & 0.091 \\
$\begin{array}{l}\text { N-sample } \\
\text { Jumlah Alele }\end{array}$ & 2 & 2 & 11 \\
$\begin{array}{l}\text { N-allele } \\
\text { Diversitas haplotipe } \\
\text { Haplotype diversity }\end{array}$ & 0.111 & 0.508 & 0.173 \\
\hline
\end{tabular}

yang lainnya semakin besar pula. Keragaman terkecil terdapat pada ikan baung dari Jambi. Hasil serupa juga teramati dengan menggunakan analisis truss morfometrik. Fenomena ini mengindikasikan bahwa populasi ikan baung dari Jambi mempunyai ukuran yang lebih kecil dibandingkan dua populasi lainnya.

Secara statistik dengan menggunakan AMOVA (Analysis Molecular Variance) menunjukkan bahwa terdapat perbedaan genetik secara nyata antara populasi ikan baung yang diuji $(P<0,05)$ berdasarkan frekuensi haplotipenya. Perbedaan ini disebabkan ikan baung dari Sungai Batanghari mempunyai major composite haplotype yang berbeda dengan ikan baung dari kedua lokasi lainnya yaitu Wonogiri dan Jatiluhur. Ikan baung dari Jambi didominasi oleh haplotipe \# 1 , ikan baung Wonogiri didominasi oleh haplotipe \# 3 dan \# 4, sedangkan ikan baung dari Jatiluhur hanya didominasi oleh haplotipe \# 3 . Keadaan ini mengindikasikan bahwa struktur populasi ikan baung dari Jambi berasal dari sumber yang berbeda dari sub spesies baung yang lainnya.

Jarak genetik ( $\mathrm{Da}$ ) yang dihitung menurut Takezaki \& Nei (1996) berdasarkan situs restriksi dari 4 enzim antara koleksi ikan baung tertera pada Tabel 3. Jarak genetik rata-rata antara populasi ikan baung adalah sekitar 0,752 . Dendrogram yang dibentuk berdasarkan jarak genetik tersebut menunjukkan bahwa koleksi baung dari Jatiluhur dan Wonogiri mempunyai jarak genetik lebih dekat dibandingkan jarak genetik antara koleksi ikan baung dari Jambi dengan salah satu

Tabel 3. Jarak genetik, ikan baung (Mystus nemurus) dari Jambi, Wonogiri, dan Jatiluhur Table 3. Genetic distance of Mystus nemurus collected from Jambi, Wonogiri, and Jatiluhur

\begin{tabular}{lccc}
\hline & Jambi & Wonogiri & Jatiluhur \\
\hline Jambi & xxxxxxxxxxxx & 1.000 & 1.000 \\
Wonogiri & & $x x x x x x x x x x x x$ & 0.255 \\
Jatiluhur & & & $x x x x x x x x x x x x$ \\
\hline
\end{tabular}
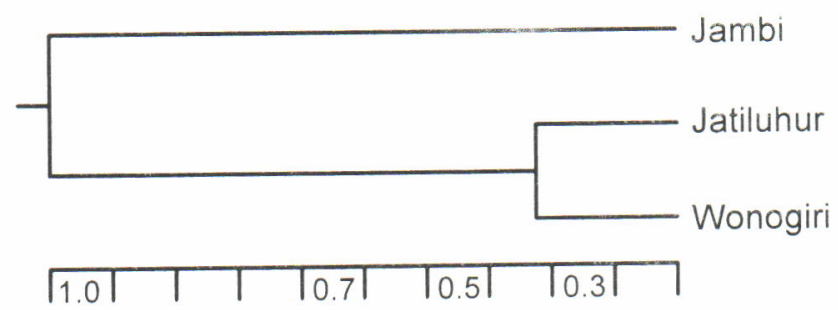

Gambar 3. Dendrogram ikan baung (Mystus nemurus) dari Jambi, Jatiluhur, dan Wo logiri

Figure 3. Dendrogram of Mystus nemururs collected from Jambi, Jatiluhur, anc' $W$ onogiri 
koleksi dari kedua populasi lainnya (Gambar 3). Nilai Da pada ikan baung ini relatif lebih besar dibandingkan jarak genetik antara ikan dari populasi yang terdiri dari sub-spesies yang sama, seperti pada ikan nila (Nugroho et al., 2002), king fish (Nugroho et al., 2001), dan greater amberjack (Nugroho et al., 2000). Lebih lanjut, nilai tersebut setara jika dibandingkan dengan jarak genetik pada perbandingan antara ikan greater amberjack (ikan karang) dari sub spesies yang berbeda (Nugroho, 1998). Keadaan ini mengindikasikan bahwa adanya kemungkinan ikan baung dari Jambi merupakan salah satu sub spesies lainnya dari ikan baung. Hal ini perlu ditindaklanjuti lebih jauh lagi dengan dukungan informasi secara anatomi.

\section{KESIMPULAN}

Terdapat perbedaan genetik yang nyata antara ikan baung ras Jambi dengan Ras Jatiluhur dan Ras Wonogiri

\section{UCAPAN TERIMA KASIH}

Penulis mengucapkan terima kasih kepada Badan Riset Kelautan dan Perikanan atas dukungan dana dalam pelaksanaan penelitian ini. Penelitian ini merupakan salah satu bagian kegiatan yang didanai dari Proyek Riset Perikanan Budidaya Air Tawar, Bogor yang bersumber dari APBN tahun 2003.

\section{DAFTAR PUSTAKA}

Carvalho, G..R. and T.J. Pitcher. 1995. Molecular Genetics in Fisheries. Chapmann \& Hall, London, 255 pp.

Ferguson, A.J., A.J. Taggart, P.A. Prodohl, O. McMeel, C. Thompson, C. Stone, P. McGinnity, and R.A. Hynes. 1995. The application of molecular markers to study and conservation of fish populations, with special reffernce to Salmo. Journal of Fish Biology, 47: 103-126.

Gardner, E.J., M.J. Simmons, and D.P. Snustad. 1991 Principle of Genetics. John Weley \& Sons. New York.

Martin, A.P., R. Humphreys, and S.R. Palumbi. 1992. Population genetic structure of the armorhead, Pseudpentaceros wheeleru, in the North Pacific Ocean: Application of the polymerase chain reaction to fisheries problems. Canadian Journal Fisheries Aquatic Science, 49: 2,386--2,391

Nei, M. and F. Tajima. 1981. DNA polymorphism detectable by restriction endonucleases. Genetics, 97: $145--163$
Nugroho, E., N.A. Wahyudi, dan Sudarto. 1991 Penentuan Jenis Kelamin Ikan Mas dengan Membandingkan Bentuk Tubuh Melalui Teknis "truss morfometrics". Buletin Penelitian Perikanan Tawar Balitkanwar. Bogor, 10(1)

Nugroho, E., M. Takagi, and N. Taniguchi. 1997. Practical manual on detection of DNA polymorphism in fish population study. Bulletin of Marine Science and Fisheries, Kochi University, 17: 109--130.

Nugroho, E. 1998. Studies on the Detection of Microsatellite DNA and Estimation of the Genetic Variability of Carangid-Genus Seriola. M.Sc. Thesis. Kochi University, 76 pp.

Nugroho, E., N. Taniguchi, K. Kato, and S. Miyashita. 2000. Genetic difference among seed populations of greater amberjack used in aquaculture farm of Japan. Suisanzoshoku, 48(4): 665--674.

Nugroho, E. 2001. Population Genetic Studies on the Aquaculture Fish in Genus Seriola for Their Risk Management. PhD Thesis. Tohoku University, 123 pp.

Nugroho, E., D.J. Ferrell, P. Smith, and N. Taniguchi. 2001. Genetic divergence of kingfish from Japan, Australia and New Zealand inferred by microsatellite DNA and mitochondrial DNA control region markers. Fisheries Science, 67: 843--850

Nugroho, E., A. Widiati, Imron, dan T. Kadarini. 2002. Keragaan genetik ikan nila gift berdasarkan polimorfism mitokondria DNA D-loop. (submitted to Jurnal Penelitian Perikanan Indonesia)

Park, L.K and P. Morgan. 1995. Developments in molecular genetic techniques in fisheries. In Molecular Genetics in Fisheries by Carvalho, G.R and Pitcher, T.J. (Eds.) Chapmann \& Hall, London, $1--28$.

Royce, W.F. 1984. Introduction to the Practise of Fishery Science. Academic Press Inc. Orlando, San Diego, New York, London, Toronto, Montreal, Sydney, Tokyo.

Schneider, S., J.M. Kueffer, D. Roessli, and L. Excoffier. 1996. Arlequin: A Software Package for Population Genetics. Univ. of Geneva, Geneva, Switzerland.

Tayaman, M., R. Reyes, J. Danting, E. Diopnisio. F Longalong, T. Gonzales, and M. Danting. 1991 Genetic Improvement of Farmed Tilapias. In Maclean, J.L. and L.B. Dizon (Eds.). ICLARM Report 1990. ICLARM. Manila.

Takezaki, N and M. Nei. 1996. Genetic distance and reconstruction of phylogenetic trees from microsatellite DNA. Genetics, 144: 389--399.

Ward, R.D and P.M. Grewe. 1995. Appraisal of molecular genetic techniques in fisheries. In Molecular Genetics in Fisheries, by Carvalho, G.R and Pitcher, T.J. (Eds.) Chapmann \& Hall, London, p. 55--80. 